\title{
Effect of vitamin E supplementation on immune status and $\alpha$-tocopherol in plasma of piglets *
}

\author{
M Hidiroglou 1, TR Batra 1, ER Farnworth 1, F Markham 2 \\ ${ }^{1}$ Centre for Food and Animal Research, Agricultural and Agri-Food Canada, Ottawa, \\ ON, K1A OC6; \\ 2 Atlantic Veterinary College, University of Prince Edward Island, Charlottetown, \\ PEI, C1A 4P3, Canada
}

(Received 30 January 1995; accepted 10 May 1995)

\begin{abstract}
Summary - Twelve (Yorkshire) gilts were assigned to 2 dietary fat supplement groups starting at $57 \mathrm{~d}$ of gestation. Group 1 received no fat and Group 2 was supplemented with $5 \%$ Canola oil. Each group was supplemented with $0.1 \mathrm{ppm}$ Se and $22 \mathrm{IU}$ of DL- $\alpha$-tocopherol acetate $/ \mathrm{kg}$ of feed. Colostrum (d 0 ) and milk $(7,14,21$ and $28 \mathrm{~d}$ post partum) were sampled from gilts. At farrowing 3 piglets from each gilt of both groups were injected with $\alpha$-tocopherol at birth (500 IU) and at 7 and $14 \mathrm{~d}(1000 \mathrm{IU})$ of age and 3 piglets were injected with saline and used as control. Blood samples were taken from the newborn piglets at birth and at $7,14,21,28$ and $35 \mathrm{~d}$ of age. $\alpha$-Tocopherol concentration in the colostrum of gilts was significantly higher than in the milk. Plasma $\alpha$-tocopherol concentrations and antibody titres to Keyhole limpet haemocyanin of piglets injected with vitamin $E$ were significantly higher than the control piglets. Vitamin $E$ injected piglets had significantly higher $\alpha$-tocopherol concentrations in spleen, liver, kidney, heart, lung and hip muscle than the control piglets.
\end{abstract}

\section{vitamin E / immune status / dietary fat / piglet}

Résumé - Effet de la vitamine $E$ sur l'état immunitaire et sur la concentration en vitamine $E$ plasmatique chez le porcelet. $\dot{A} 57 j$ de gestation, 12 truies (Yorshire) ont été partagées en 2 groupes. Groupe I : aucun supplément en matières grasses supplémentaires apporté à leur ration. Groupe II : supplément de $5 \%$ d'huile de colza. En plus, chaque truie a reçu 0,1 ppm de sélénium et 22 UI de DL$\alpha$-tocophérol acétate par $\mathrm{kg}$ de régime. Le colostrum (jour 0) et le lait $(7,14,21$ et $28 \mathrm{j}$ ) post-partum ont été échantillonnés. Lors de la mise bas, 3 porcelets de chaque truie ont reçu $500 \mathrm{Ul}$ d' $\alpha$-tocophérol, puis 2 injections de $1000 \mathrm{UI}$ à 7 et $14 \mathrm{j}$. Le même nombre de porcelets a reçu une solution saline à leur naissance, puis à 7 et $14 \mathrm{j}$. Des échantillons de sang ont été prélevés chez les porcelets à leur naissance, puis respectivement à $7,14,21,28$ et $35 \mathrm{j}$. Le colostrum était plus riche en vitamine $E$ que les laits. $L$ ' $\alpha$ tocophérol plasmatique ainsi que les taux d'anticorps à l'hæmocyanine Keyhole étaient plus élevés chez

\footnotetext{
* CFAR contribution No 2290
} 
les porcelets injectés avec de la vitamine $E$ que chez les témoins. Les porcelets traités à la vitamine $E$ avaient également des concentrations plus fortes en vitamine $E$ dans la rate, le foie, les reins, le ccur, les poumons et les muscles de la cuisse que les témoins.

vitamine E / état immunitaire / matière grasse alimentaire / porcelet

\section{INTRODUCTION}

One factor contributing to loss of neonatal pigs is their low body energy reserves. Addition of $10-15 \%$ fat to sow diets during the late gestation can increase the body fat of the newborn pig (Pond, 1991). Malm et al (1976) reported that gestating sows fed corn oil had lower plasma vitamin $E$ than those fed lard, and related this to differences in dietary polyunsaturated fatty acids. They also stated that piglets had significantly higher serum $\alpha$-tocopherol concentrations than their dam, illustrating efficient placental transfer. The major function of vitamin $\mathrm{E}$ in the body is considered to be as an antioxidant (Machlin, 1980). This is important in maintaining cell membrane integrity and immune status of the animal. Low vitamin $E$ in piglets induces a variety of lesions such as skeletal muscle degeneration, mulberry heart disease (Van Vleet, 1980) and depression of immune function (Peplowski et al, 1981).

Ulirey (1981) also reported that vitamin $E$ may also play a role in the immune response to infection. Supplementation of $30 \mathrm{IU}$ of vitamin $\mathrm{E} / \mathrm{kg}$ of feed should be adequate under most circumstances. When the diets contained considerable amounts of oxidized fat or the pigs were stressed by infection, even higher levels of vitamin $\mathrm{E}$ may be necessary. The administration of high levels of vitamin $E$ has been suggested as one method that can be used to improve a depressed immune response of a stressed pig. Duncan et al (1960) reported that lowfat diet would adversely affect the absorption of $\alpha$-tocopherol and that increasing the fat content would improve absorption. Supple- mentation of vitamin $E$ to dams improve vitamin E status of their newborn. Intramuscular injection of vitamin $E$ directly to the neonatal and young piglets could perhaps be more efficient.

The objectives of this study were to determine the effects of dietary fat on milk $\alpha$-tocopherol concentration of gilts and the effect of injections of vitamin $E$ in the piglets born from these gilts on their plasma $\alpha$-tocopherol levels, serum immunoglobulin (IgG) levels, and antibody titres to Keyhole Limpet Haemocyanin (KLH).

\section{MATERIALS AND METHODS}

\section{Experimental design and diets}

Gilts from the minimum disease herd of the Centre for Food and Animal Research were fed a pelleted standard growing diet (Hidiroglou et al, 1993) containing $22 \mathrm{lU} / \mathrm{kg} \alpha$-tocopherol until they reached $95 \mathrm{~kg}$ body weight. At their next oestrus they were bred to randomly selected boars. Gilts were fed the diet (Hidiroglou et al, 1993) at the rate of $2 \mathrm{~kg} / \mathrm{d}$. Thirty days after mating, gilts were tested with a Prognosticator probe (Animark Co, Denver, CO, USA) to confirm pregnancy. On d 57 of gestation 12 gilts were assigned to 2 diet groups as follows: Group 1: 6 gilts fed no-fat gestation diet; Group 2: 6 gilts fed gestation diet with $5 \%$ Canola oil. Gilts were fed a gestation diet (table 1) twice daily in individual feeding crates during pregnancy. At farrowing 3 of the newborn piglets from each gilt of both groups were administered $500 \mathrm{IU}$ of $\mathrm{D}$ - $\alpha$-tocopherol (Stuart Products, Bedford, TX, USA) by intramuscular injection and 3 piglets used as controls were injected with a saline solution in the crural muscle. The treated piglets were injected again at 7 and $14 \mathrm{~d}$ with $1000 \mathrm{IU}$ of vitamin $\mathrm{E}$ and $10 \mathrm{mg}$ of $\mathrm{KLH}$. Water 
Table I. Percentage (DM basis) composition of gestation diets.

\begin{tabular}{lll} 
Ingredients & $\begin{array}{c}\text { No-fat } \\
\text { gestation } \\
\text { diet }\end{array}$ & $\begin{array}{c}\text { Canola oil (5\%) } \\
\text { gestation } \\
\text { diet }\end{array}$ \\
\hline Corn & 50 & 50 \\
Soybean meal & 23 & 23 \\
Corn starch & 19 & 14 \\
Wheat bran & 2 & 2 \\
Canola oil & - & 5 \\
Limestone & 1.5 & 1.5 \\
Dicalcium phosphate & 1.5 & 1.5 \\
Salt (iodized) & 0.5 & 0.5 \\
Lignosol a & 1.5 & 1.5 \\
Vitamin b & 0.5 & 0.5 \\
Mineral premix ${ }^{\mathrm{c}}$ & 0.5 & 0.5 \\
-.. & & \\
\hline
\end{tabular}

a Lignosol FG (Reed Ltd, Chem Div, Lignin products, Quebec); a binding agent. b Premix provides per $\mathrm{kg}$ of diet: 8250 IU vitamin A; 550 IU vitamin D; 22 IU $\alpha$-tocopheroi; $4.4 \mathrm{mg}$ vitamin $\mathrm{K} ; 3 \mathrm{mg}$ thiamine; $8 \mathrm{mg}$ riboflavin; $44 \mathrm{mg}$ niacin; $33 \mathrm{mg}$ calcium pantothenate; $0.028 \mathrm{mg}$ vitamin $\mathrm{B}_{12} ; 500 \mathrm{mg}$ choline chloride; $0.25 \mathrm{mg}$ D-biotin; $1 \mathrm{mg}$ folic acid; and $3 \mathrm{mg}$ vitamin $B_{6}$. c Premix provides per kg of diet: $8 \mathrm{mg} \mathrm{Cu} ; 80 \mathrm{mg} \mathrm{Fe}$; $20 \mathrm{mg} \mathrm{Mn} ; 75 \mathrm{mg} \mathrm{Zn;} \mathrm{and} 0.2 \mathrm{mg}$ Se.

was available ad libitum for sows and piglets during the whole experiment. After farrowing, the gilts were switched to a pelleted lactation diet (table II) containing the same levels of vitamin E and fat as during gestation. During lactation gilts received feed ad libitum.

\section{Blood and milk sampling}

Samples of colostrum ( $d$ 0) and milk on d 7, 14, 21 and 28 were collected by hand after intramuscular injection of 30-50 IU of oxytocin. Approximately $30 \mathrm{ml}$ of colostrum or milk was obtained at each sampling. Blood samples were taken from newborn piglets $3 \mathrm{~h}$ after suckling and then from piglets at $7,14,21,28$ and $35 \mathrm{~d}$ of age. Blood samples of $1 \mathrm{ml}$ were taken from vena cava. Plasma was removed from the blood after centrifugation at $1000 \mathrm{~g}$ and stored at $-70^{\circ} \mathrm{C}$ until analysis.
Table II. Percentage (DM basis) composition of lactation diets.

\begin{tabular}{lll}
$\begin{array}{l}\text { Ingredients } \\
\text { Corn }\end{array}$ & $\begin{array}{c}\text { No-fat } \\
\text { lactation } \\
\text { diet }\end{array}$ & $\begin{array}{c}\text { Canola oil (5\%) } \\
\text { lactation } \\
\text { diet }\end{array}$ \\
Soybean meal & 46.9 & 46.9 \\
Barley & 17 & 17 \\
Canola oil & 25 & 25 \\
Corn starch & - & 5 \\
Limestone & 5 & - \\
Dicalcium phosphate & 1.3 & 1.3 \\
Salt (iodized) & 1.8 & 1.8 \\
Lignosol a & 0.5 & 0.5 \\
Vitamin premix & 1.5 & 1.5 \\
Mineral premix & & \\
& 0.5 & 0.5 \\
\hline
\end{tabular}

a,b,c See table I.

\section{Blood and milk analyses}

$\alpha$-Tocopherol concentrations in plasma, colostrum and milk were analyzed by HPLC, according to McMurray and Blanchflower (1979). Serum immunoglobulin (IgG) was determined at 7, 14, 28 and $35 \mathrm{~d}$ by single radial immunodiffusion procedure using a specific SRID kit (VMRD, Inc, Pullman, WA, USA). Tests were performed using the standards provided by the manufacturer and according to their guidelines. An enzyme immunoassay (ELISA) was used to measure specific antibody response to $\mathrm{KLH}$. It was performed according to standard techniques (Coligan et al, 1992). One hundred microlitres of $\mathrm{KLH}$ at $10 \mu \mathrm{g} / \mathrm{ml}$ was adsorbed to polystyrene microlitre plates (Costar, BioRad Laboratories, Mississauga, ON, Canada) in $0.05 \mathrm{M}$ bicarbonate buffer, $\mathrm{pH}$ 9.6. After addition and serial dilution of serum, specific antibody was detected by addition of peroxidase-labelled anti-swine immunoglobulin (Dako Laboratory, Denmark) and substrate (2,2'-azinobis(3-ethylbenzthiazoline)-6-sulfonic acid (ABTS) and $\mathrm{H}_{2} \mathrm{O}_{2}$ ). Plates were read on an automated microlitre reader and OD490 0.1 was chosen as the endpoint for titration. The antibody titres for the $\mathrm{KLH}$ were determined at $7,21,28$ and $35 \mathrm{~d}$ of age and are given as the reciprocal of the last dilution with a positive reading. 


\section{Tissue samples}

Twenty-four pigs were killed by exsanguination at $28 \mathrm{~d}$ of age. One pig from each of the groups of 12 gilts was killed, one from the vitamin E-injected group and one from control (no vitamin $E$ injection) group. Portions of spleen, liver, kidney, heart, lung and hip muscle (gluteus) were removed. All tissues were stored at $-70^{\circ} \mathrm{C}$ until they were analyzed for $\alpha$-tocopherol. Tissue samples were prepared for $\alpha$-tocopherol determination according to the method of Ingold et al (1987). Quantization of $\alpha$-tocopherol in tissues was performed by HPLC using a fluorescent detector (McMurray and Blanchflower, 1979).

\section{Statistical analysis}

The data on $\alpha$-tocopherol concentrations in milk of gilts were analyzed by repeated measure anal$y$ sis of variance using the SAS general linear model procedure (SAS, 1989). The following linear model was used:

$$
Y_{i j k}=\mu+D_{i}+G_{j}\left(D_{i}\right)+T_{k}+(D T)_{i k}+e_{i j k}
$$

Where $Y$ is the concentration of $\alpha$-tocopherol in the milk at a specific time; $\mu$ is the overall mean; $D$ is the effect of dietary fat supplementation; $G(D)$ is the effect of gilt within dietary fat supplementation; $T$ is the effect of time of sample collection; $(D T)$ is the interaction of dietary fat with time; and $e$ is the error term. Colostrum data $(\mathrm{d} 0)$ were not combined with the milk data $(7,14,21,28 \mathrm{~d})$ as mean levels and variances were quite different.

Piglet mean values for $\alpha$-tocopherol in the plasma, serum IgG levels and antibody titres to $\mathrm{KLH}$ for each gilt and time were analyzed rather than individual piglet values, as the among-litter error was significantly larger than the amongpiglet error. Logarithms of serum IgG levels and antibody titres to $\mathrm{KLH}$ were taken to stabilize the variances which increased with increasing means. The following model was used for the analysis of plasma $\alpha$-tocopherol concentration, serum IgG levels and antibody titres of KLH of piglets:

$$
\begin{aligned}
Y_{i j k l} & =\mu+D_{i}+V_{j}+(D V)_{i j}+T_{k}+(D T)_{i k}+(V T)_{j k} \\
& +(D V T)_{i j k}+e_{i j k l}
\end{aligned}
$$

Where $Y$ is the concentration of $\alpha$-tocopherol or serum IgG levels or antibody titres to $\mathrm{KLH}$ at a specific time; $\mu$ is the overall mean; $D$ is the effect of dietary fat; $V$ is the effect of vitamin $E$ injection; $(D V)$ is the interaction of dietary fat with vitamin $E$ injection; $T$ is the effect of time of sampling; $(D T)$ is the interaction of dietary fat with time; (VT) is the interaction of vitamin E injection with time; (DVT) is the interaction among dietary fat, vitamin $E$ injection and time; and $e$ is the error term. ANOVA were performed on the logarithms of the tissue vitamin $E$ concentrations (SAS, 1989). The model included the effects of dietary fat, vitamin $E$ injection and interaction of the dietary fat with vitamin $E$ injection. Logarithms of the tissue $\alpha$-tocopherol concentrations were taken to stabilize the variances which increased with increasing concentrations (Snedecor and Cochran, 1980).

\section{RESULTS AND DISCUSSION}

\section{Experimental diets and animal weights}

The mean and standard error $(X \pm S E)$ of litter size was $10.2 \pm 0.35$ ( $9.7 \pm 0.38$ alive) with an average piglet live birth weight of $1.27 \pm 0.04 \mathrm{~kg}$. These parameters did not show significant effect due to dietary fat supplementation. This may be due to the small number of litters examined.

\section{Colostrum and milk $\alpha$-tocopherol concentration in gilts}

The effect of dietary fat on colostrum and milk $\alpha$-tocopherol concentration was not significant $(P>0.05)$. The effect of day of sampling on milk $\alpha$-tocopherol concentration was significant $(P<0.05)$. Milk $\alpha$-tocopherol concentrations decreased with advance in lactation in both no-fat and Canola oil supplemented groups (table III). This was similar to the trend observed by Malm et al (1976) in lactating sows. $\alpha$-Tocopherol concentration in the colostrum was significantly $(P<0.05)$ higher than in the milk in both groups. Similar results were also reported by 
Nielsen et al (1973). There was a slight decline in the $\alpha$-tocopherol concentration in the milk of gilts from 7 to $28 \mathrm{~d}$ of lactation in both groups (table III).

\section{Plasma $\alpha$-tocopherol concentrations in piglets}

At birth plasma $\alpha$-tocopherol concentrations in the piglets of the control groups were very

Table III. Least square means and standard errors of $\alpha$-tocopherol $(\mu \mathrm{g} / \mathrm{ml})$ in the colostrum and milk of gilts.

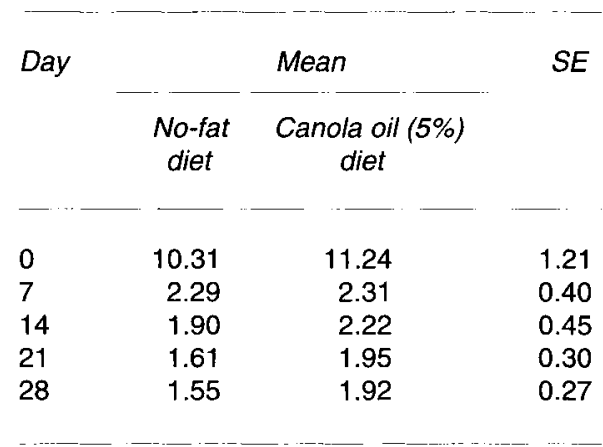

low and could not be measured (table IV). This observation is similar to that of Dvorak (1974) who found very low vitamin E concentrations in the plasma of piglets. This is mainly due to inefficient placental transfer of tocopherol (Young et al, 1977). Schlotke et al (1978) reported that $\alpha$-tocopherol status of the newborn piglet before ingesting colostrum is not dependent on the vitamin $E$ supply of the sows. The low plasma $\alpha$-tocopherol concentration observed in newborn piglets born from gilts receiving $22 \mathrm{IU}$ vitamin $E$ in the diet either with no fat or $5 \%$ Canola oil did not manifest any clinical vitamin $E$ deficiency symptoms. Chung et al (1992) reported that dietary $D-\alpha$-tocopherol may be more effectively absorbed and retained by weanling swine than $\mathrm{DL}-\alpha$-tocopheryl acetate.

The intake of colostrum and its content of vitamin $E$ played a decisive role on the plasma $\alpha$-tocopherol concentrations of piglets. Dietary fat supplementation to the gilts had no significant $(P>0.05)$ effect on the plasma $\alpha$-tocopherol concentration of the piglets. The effect of vitamin $E$ injection to the piglets was significant $(P<0.05)$ on

Table IV. Least square means and standard errors of $\alpha$-tocopherol $(\mu \mathrm{g} / \mathrm{ml})$ in the blood plasma of piglets.

Piglet

age (d)

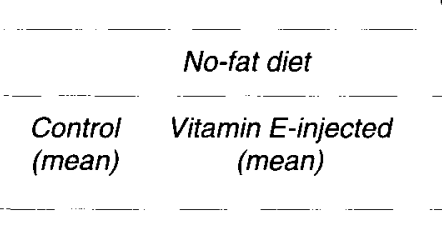

$\begin{array}{ll}0 & \text { ND } \\ 7 & 2.74^{a} \\ 14 & 2.69^{a} \\ 21 & 2.52^{a} \\ 28 & 2.47^{a} \\ 35 & 1.43\end{array}$

Sow diet

\begin{tabular}{lccc} 
& \multicolumn{3}{c}{ Canola oil (5\%) diet } \\
& $\begin{array}{c}\text { Control } \\
\text { (mean) }\end{array}$ & $\begin{array}{c}\text { Vitamin E-injected } \\
\text { (mean) }\end{array}$ & $S E$ \\
\hline & & & \\
0.58 & $\mathrm{ND}$ & 6.21 & 0.76 \\
0.58 & $3.14^{\mathrm{a}}$ & $13.30^{\mathrm{b}}$ & 0.76 \\
0.58 & $2.81^{\mathrm{a}}$ & $9.78^{\mathrm{b}}$ & 0.76 \\
0.58 & $2.72^{\mathrm{a}}$ & $7.21^{\mathrm{b}}$ & 0.76 \\
0.58 & $2.57^{\mathrm{a}}$ & $5.07^{\mathrm{b}}$ & 0.76 \\
0.58 & 1.66 & 2.57 & 0.76
\end{tabular}

ND $=$ not detected. a,b Means with different letters within the same row are different $(P<0.05)$. 
the plasma $\alpha$-tocopherol concentration. Plasma $\alpha$-tocopherol concentrations of piglets after ingestion of colostrum and injection of vitamin E (500 IU) was significantly $(P<0.05)$ higher than the control pigs before colostrum intake. Plasma $\alpha$-tocopherol concentrations of piglets injected with vitamin $E$ at birth (500 IU) and again at 7 and $14 \mathrm{~d}$ of age (1 $000 \mathrm{IU})$ were significantly $(P<0.05)$ higher than the control piglets from 7 to $28 \mathrm{~d}$ of age (table IV). Plasma $\alpha$-tocopherol concentrations on $\mathrm{d} 7$ were highest in both the control and vitamin E-injected group, which decreased from 14 to $35 \mathrm{~d}$ of age (table IV).

\section{Immunoglobulin (IgG) levels and antibody titres to $\mathrm{KLH}$ in the piglets}

Effects of dietary fat and vitamin $E$ injection were not significant for IgG concentration in the piglets, while the effect of time of sampling was significant $(P<0.05)$. Serum IgG levels averaged across days were similar for the vitamin E-injected and control group. Serum IgG concentration was highest on day 7 and then slowly declined with age (table V). Similar results were reported by Hidiroglou et al (1992). Effect of vitamin $E$ supplementation was significant $(P<0.05)$ for titre to $\mathrm{KLH}$. Titres to $\mathrm{KLH}$ were higher at 28 and $35 \mathrm{~d}$ than at $21 \mathrm{~d}$ of age (table $\mathrm{V}$ ). This suggests that the peak for antibody titres to KLH was reached about $14 \mathrm{~d}$ after the second vaccination. Similar results were also reported by Hidiroglou et al (1992) in calves. The antibody titres to KLH in the vitamin E-injected piglets were significantly $(P<0.05)$ higher than the control piglets at $21 \mathrm{~d}$ (17 vs 2), $28 \mathrm{~d}$ (121 vs 261) and at $35 \mathrm{~d}$ (760 vs 175).

\section{Tissue $\alpha$-tocopherol concentrations}

The effect of dietary fat was not significant $(P>0.05)$ while the effect of treatment was significant $(P<0.05)$ for the concentrations

Table V. Least square means and standard errors of serum immunoglobulin (lgG) level and titre to $\mathrm{KLH}$ in the piglets.

\begin{tabular}{|c|c|c|c|c|}
\hline \multirow[t]{2}{*}{ Age $(d)$} & \multicolumn{2}{|c|}{ Control } & \multicolumn{2}{|c|}{ Vitamin E-injected } \\
\hline & Mean & $S E$ & Mean & $S E$ \\
\hline \multicolumn{5}{|c|}{ Immunoglobulin (lgG) level $(\mathrm{mg} / 100 \mathrm{ml})$} \\
\hline 7 & 159 & 10 & 162 & 10 \\
\hline 14 & 80 & 9 & 77 & 9 \\
\hline 28 & 42 & 4 & 49 & 4 \\
\hline 35 & 50 & 3 & 51 & 3 \\
\hline \multicolumn{5}{|c|}{ Titre to $K \mathrm{LH}^{1}$} \\
\hline 7 & 2 & 1 & 0 & 1 \\
\hline 21 & $2^{a}$ & 5 & $17^{\mathrm{b}}$ & 5 \\
\hline 28 & $261^{a}$ & 186 & $1216^{b}$ & 174 \\
\hline 35 & $175^{a}$ & 142 & $760^{\mathrm{b}}$ & 133 \\
\hline
\end{tabular}

$\mathrm{KLH}=$ Keyhole Limpet Haemocyanin, units are the reciprocal of the last dilution which gave a positive haemagglutination. a,b Means with different letters within the same row are different $(P<0.05)$. 
Table VI. Least square means and standard errors of $\alpha$-tocopherol concentrations $(\mu \mathrm{g} / \mathrm{g})$ in tissues of control and vitamin E-injected piglets.

\begin{tabular}{|c|c|c|c|c|}
\hline \multirow[t]{2}{*}{ Tissue } & \multicolumn{2}{|c|}{ Control } & \multicolumn{2}{|c|}{ Vitamin E-injected } \\
\hline & Mean & $S E$ & Mean & $S E$ \\
\hline Spleen & $2.83^{a}$ & 0.21 & $9.37^{b}$ & 0.57 \\
\hline Liver & $3.79^{\mathrm{a}}$ & 1.08 & $13.97^{b}$ & 1.13 \\
\hline Kidney & $2.52^{\mathrm{a}}$ & 0.92 & $13.48^{b}$ & 0.96 \\
\hline Heart & $4.03^{a}$ & 0.92 & $16.19^{b}$ & 0.96 \\
\hline Lung & $3.57^{\mathrm{a}}$ & 0.74 & $13.32^{b}$ & 0.77 \\
\hline Hip muscle ${ }^{c}$ & $2.83^{a}$ & 3.89 & $40.44^{b}$ & 4.08 \\
\hline
\end{tabular}

a,b Means with different letters within the same row are different $(P<0.05)$. $^{c}$ Hip muscle refers to the gluteus muscle.

of $\alpha$-tocopherol in all the tissues. Vitamin Einjected piglets had significantly $(P<0.05)$ higher $\alpha$-tocopherol concentrations in all the tissues than the piglets not injected with vitamin E (table VI). Various tissues responded differently to vitamin $E$ injections. The concentrations of $\alpha$-tocopherol in different tissues were similar to the ones reported by Batra and Hidiroglou (1994). The highest concentration of $\alpha$-tocopherol in the vitamin E-injected piglets was in the hip muscle followed by heart, liver, kidney, and lung (table VI).

\section{CONCLUSIONS}

Tocopherol concentration in the colostrum was significantly higher than in the milk. Dietary fat supplementation to the gilts had no significant effect on the $\alpha$-tocopherol concentration in the milk of gilts and plasma $\alpha$-tocopherol concentration in the piglets. Vitamin E injection to the piglets significantly increased the $\alpha$-tocopherol concentration in the plasma and tissues as well as antibody titres to $\mathrm{KLH}$ in the piglets.

\section{ACKNOWLEDGMENT}

The technical work of $\mathrm{J}$ Sheppard is much appreciated.

\section{REFERENCES}

Batra TR, Hidiroglou M (1994) Tissue vitamin E concentrations after single injection of $\alpha$-tocopherol in pigs. Can J Anim Sci 74, 579-581

Chung YK, Mahan DC, Lepine AJ (1992) Efficiency of dietary $D$ - $\alpha$-tocopherol and $D L-\alpha$-tocopheryl acetate for weanling pigs. J Anim Sci 70, 2485-2492

Coligan JE, Kruisbeek AM, Margulies DH, Shevach EM, Strober W (1992) Current Protocols in Immunology. John Wiley and Sons, New York, USA

Duncan WRH, Garton GA, McDonald I, Smith W (1960) Observations on tocopherol absorption by pigs. $\mathrm{Br} J$ Nutr 14, 371-377

Dvorak M (1974) Levels of vitamin $E$ in the blood plasma of suckling and weaned piglets. Acta Vet Brno 43, 103-110

Hidirogiou M, Batra TR, Laflamme LF, Markham F (1992) Possible roles of vitamin $E$ in immune response of calves. Int J Vitam Nutr Res 62, 308-311

Hidiroglou M, Farnworth E, Butler G (1993) Effects of vitamin $E$ and fat supplementation on concentration of vitamin $E$ in plasma and milk of sows and in plasma of piglets. Int $J$ Vitam Nutr Res $63,180-187$ 
Ingold KU, Burton GW, Roster DD, Hughes L, Lindsay DA, Webb A (1987) Biokinetics of and discrimination between dietary $R R R$ and SRR-tocopherol in the male rat. Lipids 3,163

Machlin LJ (1980) Vitamin E: A Comprehensive Treatise. Marcel Dekker, New York, NY, USA

Malm A, Aydin A, Kirtland D (1976) Effect of polyunsaturated fatty acids and vitamin $E$ level of the sow gestation diet on reproductive performance and on the level of $\alpha$-tocopherol in colostrum milk and dam and progeny blood serum. J Anim Sci 42, 393-399

McMurray CH, Blanchflower WJ (1979) Application of high-performance liquid chromatographic fluorescence method for the rapid determination of $\alpha$-tocopherol in the plasma of cattle and pigs and its comparison with direct fluorescence and high performance liquid chromatography ultraviolet detection methods. J Chromatogr 178, 525-531

Nielsen HE, Hojgaard NJ, Hjarde W, Leerbeck E (1973) Vitamin $\mathrm{E}$ content in the colostrum and sows' milk and sow milk yield at two levels of dietary fats. Acta Agric Scand 19, 35-38

Nowotny A (1969) Basic Exercises in Immunochemistry. Springer-Verlag, New York, USA, 143-145
Peplowski MA, Mahan DC, Murray FA, Moxon AL, Cantor AH, Ekstrom KE (1981) Effect of dietary and injectable vitamin $E$ and selenium in weanting swine antigenically challenged with sheep red blood cells. $J$ Anim Sci 51, 344-351

Pond WG (1991) Pigs and people. In: Swine Nutrition (ER Miller, DE Ulirey, AJ Lewis, eds), ButterworthHeineman, Boston, USA, 3-34

SAS (1989) SAS User's Guide. Statistics SAS Inst Inc, Cary, NC, USA

Schlotke B, Busch L, Koch F (1978) Studies on the effect of vitamin E-deficient diet in sows during pregnancy on vitamin $E$ status of newborn piglets. Zentrablt Vef Med A 25, 474-484

Snedecor GW, Cochran WG (1980) Statistical Methods (7th ed). lowa State University Press, Ames, IA, USA

Ullrey DE (1981) Vitamin E for swine. J Anim Sci 53, 1039-1056

Van Vleet JF (1980) Current knowledge of seleniumvitamin $\mathrm{E}$ deficiency in domestic animals. J Am Vet Med Assoc 176, 321-325

Young LG, Miller RB, Elmeades DE, Lun A, Smith GC, King GJ (1977) Selenium and vitamin E supplementation of high moisture corn diets for swine reproduction. J Anim Sci 45, 1051-1062 